\title{
SEASONAL CHANGES IN STREAM WATER QUALITY AND ITS EFFECTS ON MACROINVERTEBRATE ASSEMBLAGES IN A FORESTED WATERSHED
}

\author{
YURTSEVEN, I. ${ }^{1 *}-$ SERENGIL, Y. ${ }^{1}-$ PAMUKÇU, P. ${ }^{2}$ \\ ${ }^{1}$ Istanbul University Faculty of Forestry \\ Department of Watershed Management 34473 Bahçeköy-Istanbul \\ ${ }^{2} \mathrm{PhD}$ student at Istanbul University \\ (tel:+90-212-3382-400; fax:+90-212-2261-113) \\ *Corresponding author \\ e-mail:ibrahimy@istanbul.edu.tr \\ (Received $30^{\text {th }}$ Jan 2015; accepted $21^{\text {st }}$ Dec 2015)
}

\begin{abstract}
In this study, indicator macroinvertebrate individuals was used in water quality assessments due to their broad spectrum of responses of macroinvertebrates individuals with specific tolerance limit values and preferences to changes in environmental factors. Because of their indicator properties, the interactions of macroinvertebrates individuals collected from an experimental watershed in Belgrad Forest of Istanbul and sixteen environmental variables were evaluated by using principle component analysis (PCA). We concluded that stream water quality parameters should be coupled with number of macroinvertebrate individuals in order to establish the linkage between hydrochemistry with biota. Axes to be evaluated in PCA analysis were determined to defined that both of F1 (53\%) and F2 (29\%) axes explain $82 \%$ of total variance together. All macroinvertebrate individuals and dissolved oxygen were found to be loaded positively loaded to Factor 1 but electrical conductivity, total hardness, alkalinity, $\mathrm{HCO}_{3}$, organic matter and potassium, loaded negatively to Factor 1 . Water temperature, runoff, $\mathrm{pH}$, turbidity, magnesium $(\mathrm{Mg})$, sodium $(\mathrm{Na})$, nitrate nitrogen $\left(\mathrm{N}^{-\mathrm{NO}_{3}}\right)$ and ammonium nitrogen $\left(\mathrm{NH}_{4}-\mathrm{N}\right)$ and some individuals (Gerris lacustris and Perlodes microcephala) highly loaded to F2. UPGMA analysis was determined to similarity on numbers of macro invertebrate individuals in order to perform a seasonal evaluation. According to Output UPGMA dendrogram, the different number of macroinvertebrate individuals can be seen as the reflect of variable seasonal effect
\end{abstract}

Keywords: macroinvertebrates, Principal Component Analysis, forested watershed, UPGMA analysis

\section{Introduction}

Land and water interactions within watershed systems are of great importance. Determination of structural and biotic characteristics of the streams in the watersheds that accommodate various land uses will enable the land-water interactions to be further discovered. Forests have a potential to change the flow regime and the chemistry of precipitation through hydrologic processes (interception, evapotranspiration, subsurface flow, etc.) they include (Chang, 2012). Streams located in a forested watershed may flow in a variable monthly or seasonal flow regime (Allan and Castillo, 2007, Serengil et al., 2007) The variations in flow regime and water chemistry may have a potential to create a set of successive effects on a stream ecosystems. Depending on the changes in the structure of a river, habitat changes on a monthly and seasonal basis, changes in the macroinvertebrate assemblages constituting a major source of food for numerous fish and ultimately the variations occurring in fish populations are relevant ecological variables which can be measured and monitored closely. A study using freshwater organisms can be effective to reveal the degree of interventions necessary to reduce the deterioration in the watershed. Compared to several organisms, macroinvertebrate 
population dynamics respond very quickly to environmental changes, and are easily used to monitor watershed quality (Masese et al., 2014).

Macroinvertebrates are widely used in ecosystem research in recent years because they respond to a wide variety of hydrochemical effects. The benthic macroinvertebrates, in particular, have come to the forefront whereby they are sensitive to temperature, oxygen, light, bed material, chemicals, toxic substrate and the habitat characteristics and respond to sudden changes in water quality (Johnson et al., 1994). Yet, benthic macroinvertebrates are used by the investigators as biotic indicators in the studies of water-quality assessment in rivers and streams in many countries (Sundermann et al., 2014; Gies et al., 2015; Leps et al., 2015). In addition, they are being evaluated frequently in the river or lake quality assessments, long-term observations and improvement (restoration) studies (Vaughan and Ormerod, 2012). Roy et al. (2005) employed a method that compares the quality parameters in the forest and urban basins with macroinvertebrates. In this study conducted by Roy et al. (1998), species low- and high-sensitivity to the pollution have been detected, respectively, in the urban basins and forest's interior basins. A study performed by García-Roger et al. (2011) aimed to determine the effects of seasonal continuity of flow in forest waters on the macroinvertebrate communities. Garcia-Roger et al. (2011) found that continuous streams have more species compared to seasonal ones. McCord and Kuhl (2013) have also shown that April/May (spring) was higher macroinvertebrate abundance than summer and winter.

The seasonal changes in precipitation and temperature have many indirect effects on the streams. The first of these is changes in amount of water flow and water temperature due to changing temperature conditions (Connell-Buck et al., 2011). Any change in water temperature has a potential to affect chemical reactions in water (Beylich and Laute, 2012).

Istanbul is located in a temperate zone where strong seasonality in precipitation and temperature cause large fluctuations in streamflow. A dry period very common in summer months may result in zero flows in small creeks while flash floods may sweep all materials in stream channels every once or twice a year. The objective of this study is to understand how seasonal changes within the watershed will affect the water-quality and macroinvertebrate assemblages in a forested watershed at a particular site.

The monitoring phase involved measurement and observations on the numbers of macroinvertebrate individuals, water-quality and flow parameters at experimental catchments in Belgrad Forest.

\section{Materials and Methods}

This research was carried out on a stream draining a small forested watershed. The forest consists of deciduous species including oak, beech and hornbeam trees. The sampling was made the average of sampling on three different river zones per month in order to perform a seasonal evaluation (Figure 1). The study watershed covers an area of $0.775 \mathrm{~km}^{2}$, the slope is $14 \%$ and the drainage density is $3.80 \mathrm{~km} / \mathrm{km}^{2}$. A flow measurement station is located in on the creek where measurements are done in 15minute intervals. 


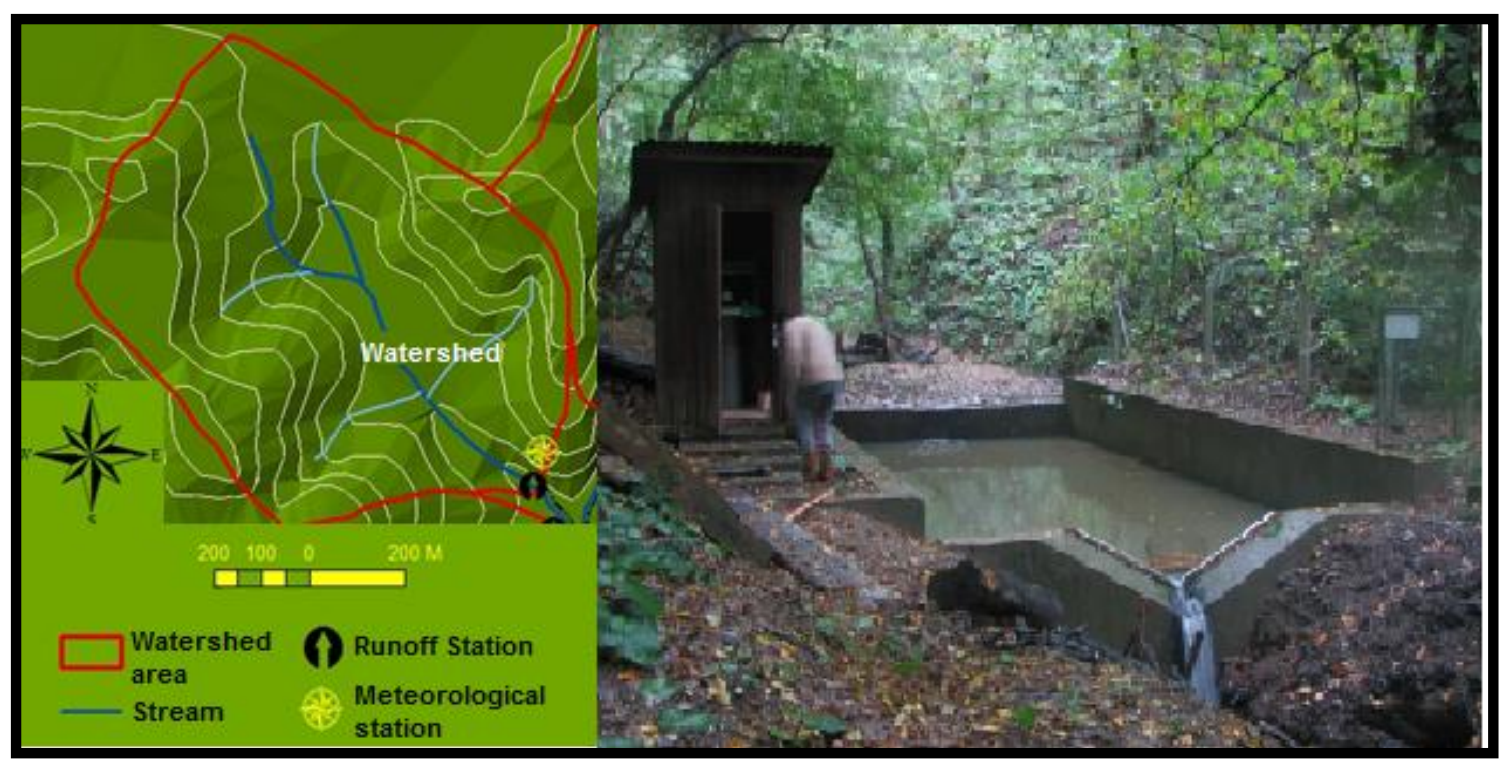

Figure 1. Watershed area map and general view of flow measurement station in Belgrad Forest.

The study consists of two main parts, which are field research and laboratory works. Field research include measurements and samplings in the field that involve collection of macroinvertebrates, determination of the instantaneous water velocity via current meter, measurements of water temperature, $\mathrm{pH}$ measurement, electrical conductivity $(\mu \mathrm{S} / \mathrm{cm})$ and dissolved oxygen content $(\mathrm{mg} / \mathrm{l})$. Some hydrochemical measurements were performed in the laboratory, such as the total hardness of the water samples, alkalinity, organic matter, nitrate nitrogen, ammonium nitrogen and the assays of $\mathrm{Ca}^{2+}, \mathrm{Mg}^{2+}, \mathrm{Na}^{+}$, $\mathrm{K}^{+}$and $\mathrm{Cl}^{-}$. Macroinvertebrates were collected and hydrochemical variables were measured on a monthly basis. The monthly values were averaged to obtain seasonal values. In this research, the macroinvertebrate assemblages and the interplays between environmental variables of the habitats in which these individuals inhabit have been explored with the Principle Component Analysis (PCA) technique. PCA is a multivariate linear analysis technique that combines regression and ordination (Jolliffe, 2005; Abdi and Williams, 2010). PCA allows the classification and distribution on the ordination plot based on the frequency status of the individuals (Jolliffe, 2011). In short, PCA is one of the multivariate statistical analysis techniques, which reveal the extent of the relationship between a cluster formed by independent variables and a cluster formed by dependent variables (Rao, 1964). Through the factor loadings assigned to the variables, PCA explains the relationships on different spatial planes and explicably shows these planes by means of the axes. Degree of proximity and distance as the distance of variables' positions on the axis to axis limits and each other indicates the status of interrelationship between these variables and the level of statistical significance.

Given the emphasis on the influence of seasons on number of macroinvertebrate individuals, a variety of analyses were done in which seasonal category was the independent variable in tests of ANOVA. Therefore, a one-way ANOVA was used to compare number of macroinvertebrate individuals among sampling seasons. The number of macroinvertebrate individuals data were also transformed $[\log (x+1)]$, to reduce the effect of the most abundant taxa. 
Sphericity test and the Kaiser-Meyer-Olkin methods were used to determine whether these data is suitable to analyze before it address PCA analysis that can be clearly detected the relationship between hydrochemical stream variables and macroinvertebrates assemblages. According to these test results, data set was found to be suitable for the PCA analysis.

Unlike the known correlation analysis, the relationships between individuals or parameters have explained on the axes in PCA analysis. Their relation degrees have been assessed by means of factor loadings $(-1 \leq \mathrm{FL} \leq+1)$ assigned to each parameter or individuals, and squared cosines ( $\mathrm{SqCos}$ ) values. Thus, factor loadings and cosine squared values of each type or parameter according to F1 and F2 axes were calculated separately.

Similarity index produced based on UPGMA software, is a simple agglomerative hierarchical clustering method, with similarity coefficient (Nei and Li, 1979). In this study, the Pearson (r) coefficients conducted an Unweighted Pair Group Method with Arithmetic Mean (UPGMA) dendrogram between months and macroinvertebrate individuals. Similarity index and distance matrix (neighbor-joining methods) were derived from Pearson (r) coefficients to determine monthly similarity analysis according to monthly total number of macroinvertebrate individuals.

\section{Results}

\section{General Results}

In field researches conducted, a total of 13 macroinvertebrate individuals (9 macroinvertebrate family) have been identified, including Gammarus pulex (Linnaeus, 1758), Gerris lacustris (Linnaeus, 1758), Ephemera vulgata (Linnaeus, 1758), Ecdyonurus dispar (Curtis, 1834), Palingenia longicauda (Olivier, 1791), Heptagenia sulphurea (Müller, 1776), Perlodes microcephala (Pictet, 1833), Calopteryx splendes (Harris, 1780), Calopteryx virgo , (Linnaeus, 1758) Tubifex sp. (Lamarck, 1816), Potamon fluviatilis (Herbst, 1785), Anisops debilis (Gerstaecker, 1873) and Habroleptoides confuse (Sartori \& Jacob, 1986). The most abundant individuals was Gammarus pulex, which can act as an indicator individual for clean water. Table 1 shows the average numbers of individuals and environmental variables for seasons with standard deviation values.

Table 1. Status of the population of macroinvertebrate individuals according to the seasons and results of measurements of environmental variables of habitats

\begin{tabular}{l|l|l|l|l}
\hline $\begin{array}{l}\text { Parameters } \\
\text { Macroinvertebrates }\end{array}$ & Spring & Summer & Fall & Winter \\
\hline Water temperature $\left({ }^{\circ} \mathbf{C}\right)$ & $11,08 \pm 3,27$ & $19,84 \pm 1,03$ & $11,84 \pm 3,97$ & $5,29 \pm 0,93$ \\
\hline Runoff $\left(\mathbf{m}^{3} / \mathbf{s n}\right)$ & $0,004 \pm 0,002$ & $0,001 \pm 0,0001$ & $0,0007 \pm 0,0002$ & $0,018 \pm 0,005$ \\
\hline Dissolved Oxygen (mg/l) & $10,54 \pm 0,56$ & $4,13 \pm 0,38$ & $4,76 \pm 0,89$ & $7,89 \pm 1,55$ \\
\hline pH & $7,29 \pm 0,02$ & $7,44 \pm 0,08$ & $7,23 \pm 0,19$ & $7,23 \pm 0,03$ \\
\hline Turbidity (NTU) & $5,31 \pm 0,73$ & $9,87 \pm 3,05$ & $7,96 \pm 3,84$ & $2,80 \pm 0,46$ \\
\hline
\end{tabular}




\begin{tabular}{|c|c|c|c|c|}
\hline $\begin{array}{l}\text { Electrical Conductivity } \\
(\mathrm{u} S / \mathrm{cm})\end{array}$ & $329,50 \pm 9,25$ & $338,75 \pm 2,94$ & $343,25 \pm 4,42$ & $\begin{array}{l}303,50 \quad \pm \\
32,65\end{array}$ \\
\hline Total hardness $\left({ }^{\circ} \mathbf{f H}\right)$ & $10,61 \pm 3,30$ & $14,69 \pm 3,00$ & $13,94 \pm 2,47$ & $12,49 \pm 1,57$ \\
\hline $\mathrm{Ca}(\mathrm{mg} / \mathrm{l})$ & $30,92 \pm 11,49$ & $25,92 \pm 2,86$ & $33,52 \pm 3,26$ & $25,65 \pm 2,91$ \\
\hline $\operatorname{Mg}(\mathrm{mg} / \mathrm{l})$ & $15,40 \pm 4,45$ & $17,39 \pm 8,31$ & $14,27 \pm 3,03$ & $15,94 \pm 2,40$ \\
\hline Alcalinity (mg/l CaCO3) & $97,15 \pm 13,60$ & $99,12 \pm 7,15$ & $141,23 \pm 79,30$ & $75,74 \pm 11,34$ \\
\hline $\mathrm{HCO}_{3}(\mathrm{mg} / \mathrm{l})$ & $118,52 \pm 16,60$ & $120,93 \pm 8,73$ & $172,29 \pm 96,74$ & $89,80 \pm 11,35$ \\
\hline Org. Mat. (mg/l O & $2,95 \pm 0,50$ & $4,44 \pm 0,84$ & $5,28 \pm 2,23$ & $1,54 \pm 0,06$ \\
\hline $\mathrm{Na}(\mathrm{mg} / \mathrm{l})$ & $3,83 \pm 0,85$ & $4,54 \pm 1,29$ & $2,72 \pm 0,37$ & $2,85 \pm 0,19$ \\
\hline $\mathrm{K}(\mathrm{mg} / \mathrm{l})$ & $1,65 \pm 0,23$ & $2,02 \pm 0,28$ & $2,29 \pm 0,95$ & $1,60 \pm 0,18$ \\
\hline N-NO3 (mg/l) & $0,92 \pm 0,18$ & $1,74 \pm 0,22$ & $2,58 \pm 1,15$ & $2,90 \pm 0,12$ \\
\hline N-NH4 (mg/l) & $0,21 \pm 0,01$ & $0,19 \pm 0,01$ & $0,27 \pm 0,10$ & $0,24 \pm 0,04$ \\
\hline Gammarus Pulex & $149 \pm 38$ & $80 \pm 74$ & $56 \pm 16$ & $88 \pm 10$ \\
\hline Gerris lacustris & $37 \pm 12$ & $30 \pm 3$ & $7 \pm 6$ & $7 \pm 6$ \\
\hline Ephemera vulgata & $12 \pm 9$ & $4 \pm 2$ & 0 & $4 \pm 2$ \\
\hline Ecdyonurus dispar & $23 \pm 3$ & $4 \pm 2$ & $1 \pm 1$ & $7 \pm 6$ \\
\hline Palingenia longicauda & $9 \pm 6$ & $5 \pm 2$ & $2 \pm 1$ & $11 \pm 7$ \\
\hline Heptagenia sulphurea & $14 \pm 11$ & $12 \pm 10$ & 0 & $21 \pm 6$ \\
\hline Calopteryx splendens & $9 \pm 3$ & $2 \pm 2$ & 0 & $5 \pm 2$ \\
\hline Calopteryx virgo & $19 \pm 2$ & $5 \pm 7$ & $2 \pm 2$ & $6 \pm 6$ \\
\hline Tubifex sp & $23 \pm 20$ & $21 \pm 17$ & 0 & $10 \pm 7$ \\
\hline Anisops debilis & $5 \pm 2$ & $1 \pm 1$ & $1 \pm 1$ & $5 \pm 2$ \\
\hline Habroleptoides confusa & $12 \pm 3$ & $2 \pm 1$ & 0 & $7 \pm 4$ \\
\hline
\end{tabular}

According to the results of field and laboratory studies performed, when considered seasonal distributions of macroinvertebrates collected from forested watersheds, it has been shown that the highest number of macroinvertebrates was reached in the spring season (number of individuals: $316 \pm$ standard deviation: 116). The total number of macroinvertebrates detected in spring is followed by winter $(174 \pm 62)$, summer $(168 \pm$ $142)$ and autumn $(75 \pm 32)$ (Figure 2$)$. When calculating seasonal water yields of this watershed, it was determined that the maximal waterflow occurs in winter (quarterly $52.40 \mathrm{~mm}$ in total) followed by autumn $(14.90 \mathrm{~mm})$, spring $(10.87 \mathrm{~mm})$ and summer $(8.13 \mathrm{~mm})$.

In box plot graph drawn according to the total number of macroinvertebrate individuals and seasons, macroinvertebrates show a downward trend from the spring to autumn while increasing their numbers in winter (Figure 3). It is seen clearly that the box representing the autumn sampling in Box plot graph is narrower than other boxes 
and smaller changes occur in the number of macroinvertebrates collected in this season than other seasons.

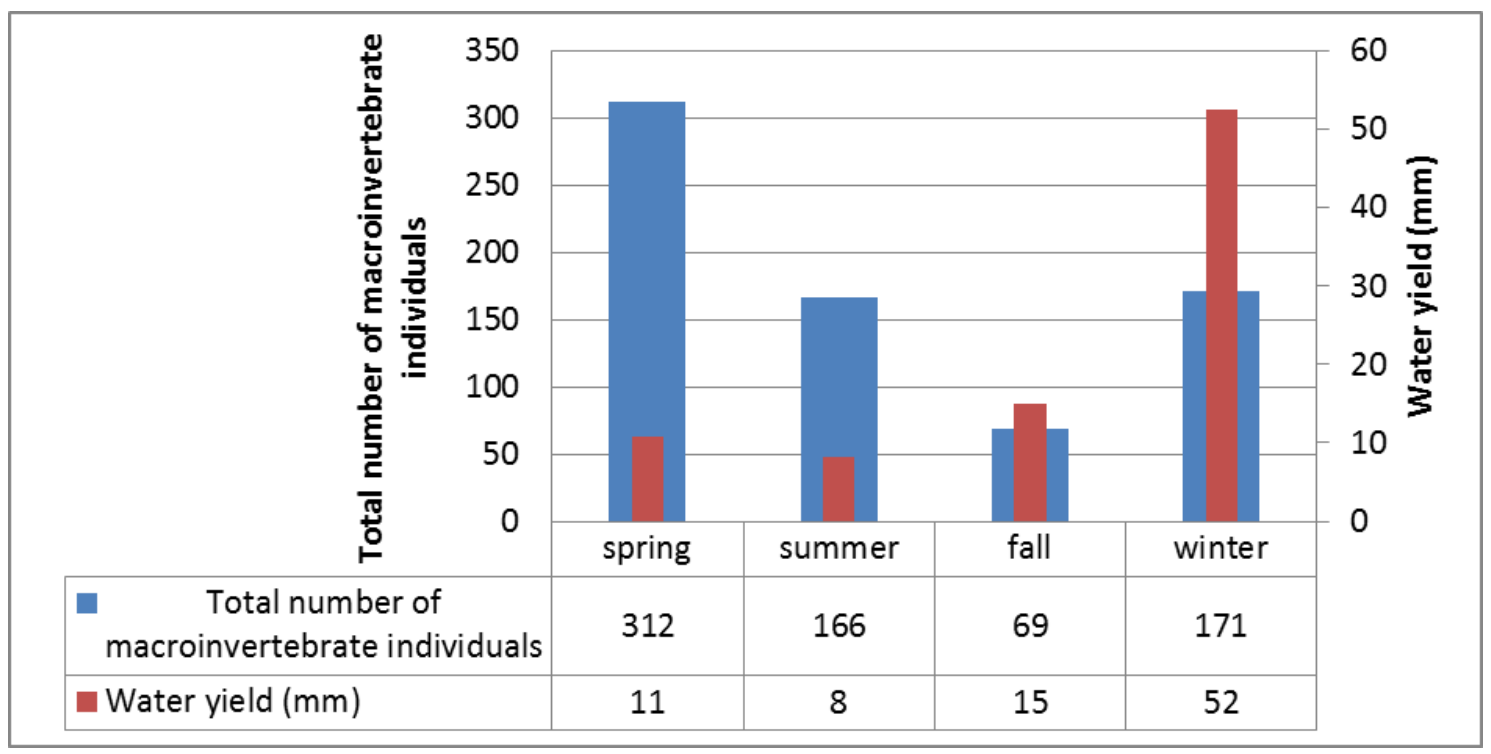

Figure 2. The total number of macroinvertebrate individuals by the seasons and stream flow conditions

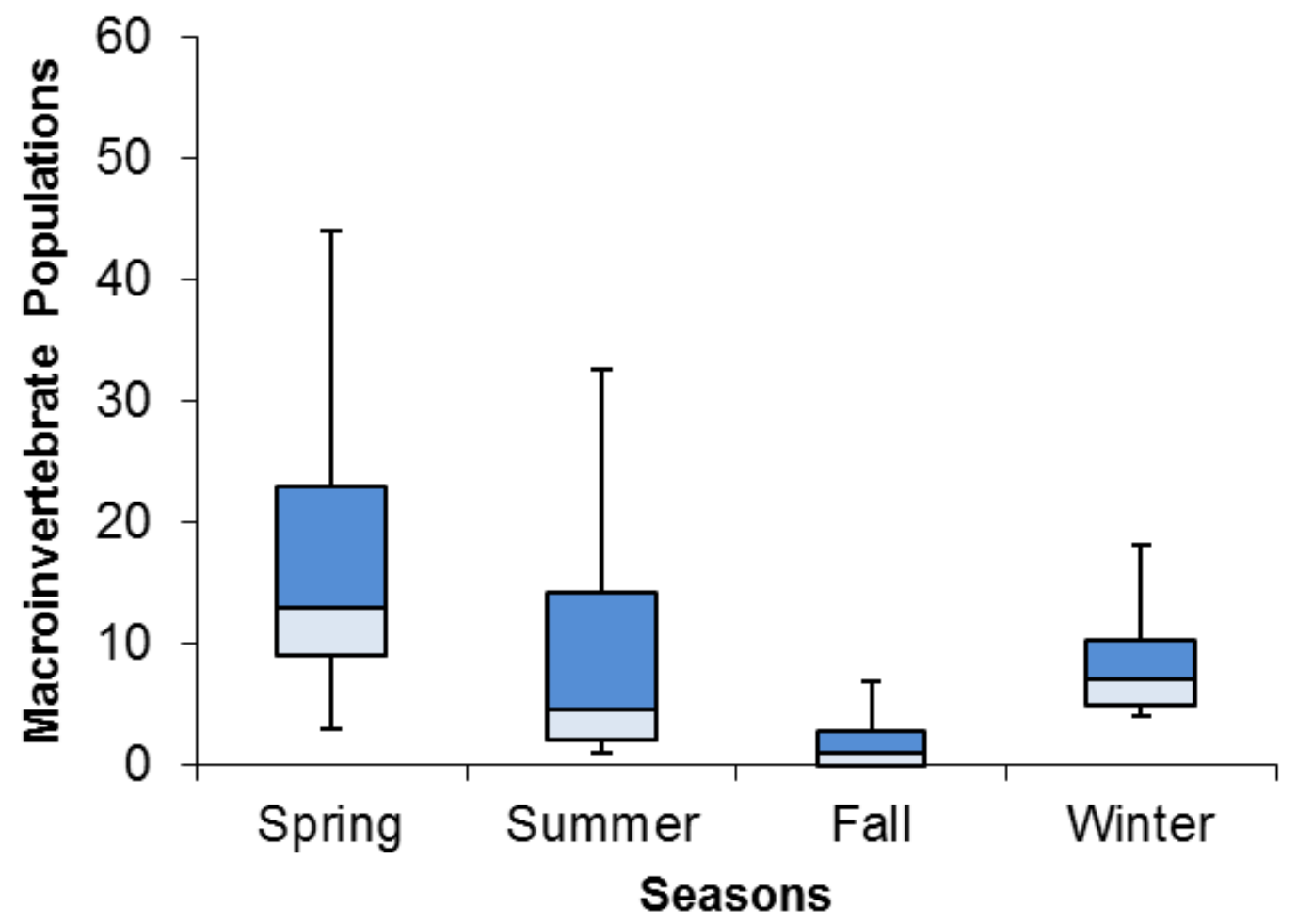

Figure 3. Representation of population dynamics of the seasonal changes of macroinvertebrate communities on the box plot 
It is seen be obviously from Figure 3 that the difference between the maximal and minimal value bars of macroinvertebrates collected in the spring is much larger than those in other seasons. Similarly, it has been clearly shown that the number of macroinvertebrate individuals collected in the spring which the box height seems to be longer than other seasons varies in a wider range than their numbers in other seasons.

A one-way ANOVA on log-transformed data to test for the effects of seasons on number of macroinvertebrate individuals (Table 2).

Table 2. ANOVA test results

\begin{tabular}{|l|l|l|l|l|l|} 
& sum of squares & degrees of freedom & mean square & Fs & $\mathbf{p}$ \\
\hline amoung groups & 2466.167 & 3 & 822.056 & 1.133 & 0.346 \\
within groups & 31190.833 & 44 & 725.246 & & \\
total & 34377 & 47 & & &
\end{tabular}

According to Table 2, one-way ANOVA, testing the effects of sampling seasons on the number of macroinvertebrate individuals, indicated that seasons had no significant effect on the number of macroinvertebrate individuals $(\mathrm{F}=1.133, \mathrm{P}<0.05)$.

\section{PCA Results}

Axes to be evaluated in PCA analysis were determined by looking percentages of explained variance by axes. Accordingly, it was defined that both F1 (53\%) and F2 $(29 \%)$ axes explain $82 \%$ of total variance together. Therefore, variables on these axes considered as the planes which clarified the relationships were placed on different points. Accordingly, high and significant relationships found for factor loadings and squared cosines of individuals and parameters are shown in Table 3.

Table 3. Factor loadings and squared cosines values of parameters according to the results of PCA analysis

\begin{tabular}{l|l|l|l|l}
\hline \multirow{2}{*}{ Parameters and Macroinvertebrates } & \multicolumn{2}{|c|}{ Factor loading $(\mathbf{F L})$} & \multicolumn{2}{c}{ Squared cosines (SqCos) } \\
\cline { 2 - 5 } & $\mathbf{F 1}$ & $\mathbf{F 2}$ & $\mathbf{F 1}$ & $\mathbf{F 2}$ \\
\hline Water temperature $\left({ }^{\circ} \mathrm{C}\right)$ & $-0,356$ & $\mathbf{0 , 9 3 5}$ & 0,126 & $\mathbf{0 , 8 7 3}$ \\
Runoff $(1 / \mathrm{s})$ & 0,518 & $\mathbf{0 , 7 6 3}$ & 0,269 & $\mathbf{0 , 6 0 3}$ \\
Dissolved Oxygen $(\mathrm{mg} / \mathrm{l})$ & $\mathbf{0 , 8 7 0}$ & $-0,303$ & $\mathbf{0 , 7 5 7}$ & 0,092 \\
pH & 0,009 & $\mathbf{0 , 9 6 2}$ & 0,000 & $\mathbf{0 , 9 2 5}$ \\
Turbidity (NTU) & $-0,638$ & $\mathbf{0 , 7 6 2}$ & 0,407 & $\mathbf{0 , 5 8 1}$ \\
Electrical Conductivity (uSS/cm) & $\mathbf{- 0 , 6 2 2}$ & 0,578 & $\mathbf{0 , 3 8 7}$ & 0,334 \\
Total hardness $\left({ }^{\circ} \mathrm{fH}\right)$ & $\mathbf{- 0 , 8 1 5}$ & 0,317 & $\mathbf{0 , 6 6 5}$ & 0,100 \\
Ca (mg/l) & $-0,392$ & $-0,224$ & 0,153 & 0,050
\end{tabular}


$\operatorname{Mg}(\mathrm{mg} / \mathrm{l})$

Alcalinity (mg/l CaCO3)

$\mathrm{HCO}_{3}(\mathrm{mg} / \mathrm{l})$

Org. Mat. (mg/l O $)_{2}$

$\mathrm{Na}(\mathrm{mg} / \mathrm{l})$

$\mathrm{K}(\mathrm{mg} / \mathrm{l})$

N-NO3 (mg/l)

$\mathrm{N}-\mathrm{NH} 4$ (mg/l)

Gammarus pulex

Gerris lacustris

Ephemera vulgata

Ecdyonurus dispar

Palingenia longicauda

Heptagenia sulphurea

Calopteryx splendes

Calopteryx virgo

Tubifex sp.

Perlodes microcephala

Anisops debilis

Habroleptoides confusa

\begin{tabular}{|c|c|c|c|}
\hline 0,292 & 0,678 & 0,085 & 0,460 \\
\hline$-0,815$ & 0,013 & 0,664 & 0,000 \\
\hline$-0,807$ & 0,038 & 0,651 & 0,001 \\
\hline$-0,823$ & 0,431 & 0,677 & 0,186 \\
\hline 0,271 & 0,959 & 0,074 & 0,920 \\
\hline$-0,958$ & 0,204 & 0,919 & 0,042 \\
\hline$-0,494$ & $-0,662$ & 0,244 & 0,438 \\
\hline$-0,521$ & $-0,829$ & 0,272 & $\mathbf{0 , 6 8 7}$ \\
\hline $\mathbf{0 , 8 9 1}$ & 0,162 & 0,794 & 0,026 \\
\hline 0,526 & 0,778 & 0,276 & 0,606 \\
\hline $\mathbf{0 , 8 8 3}$ & 0,251 & 0,779 & 0,063 \\
\hline 0,849 & 0,090 & 0,720 & 0,008 \\
\hline 0,907 & $-0,295$ & 0,823 & 0,087 \\
\hline $\mathbf{0 , 8 3 1}$ & $-0,089$ & 0,691 & 0,008 \\
\hline 0,961 & $-0,039$ & 0,924 & 0,001 \\
\hline $\mathbf{0 , 8 3 2}$ & 0,158 & 0,692 & 0,025 \\
\hline 0,718 & 0,696 & 0,515 & 0,485 \\
\hline$-0,447$ & $-0,861$ & 0,199 & 0,741 \\
\hline $\mathbf{0 , 8 9 1}$ & $-0,452$ & 0,794 & 0,204 \\
\hline 0,956 & $-0,112$ & 0,913 & 0,013 \\
\hline
\end{tabular}

If the difference is statistically significant at the $95 \%$ confidence levels, the values are marked in bold

As is seen from F1 axis of Table 3, all macroinvertebrate individuals, except for Gerris lacustris and Perlodes microcephala, loaded positively to F1. According to the F1 axis, these macroinvertebrates individuals and dissolved oxygen were found to be loaded positively to Factor 1 but electrical conductivity, total hardness, alkalinity, $\mathrm{HCO}_{3}$, organic matter and potassium, loaded negatively to Factor 1. On rising these parameters with negatively loaded to $\mathrm{F} 1$ in the river habitat environments, it appears to be a decrease in the population of associated macroinvertebrates individuals on the F1 axis (Figure 4). Apart from that, it is seen from F2 axis of the same table to be some parameters (water temperature, runoff, $\mathrm{pH}$, turbidity, magnesium $(\mathrm{Mg})$, sodium $(\mathrm{Na})$, nitrate nitrogen $\left(\mathrm{N}-\mathrm{NO}_{3}\right)$ and ammonium nitrogen $\left(\mathrm{NH}_{4}-\mathrm{N}\right)$ and some individuals (Gerris lacustris and Perlodes microcephala) highly loaded to F2. To explain clearly these relationships, a diagram showing $\mathrm{F} 1$ and $\mathrm{F} 2$ spatial planes, associated parameters according to their positions on these planes and macroinvertebrates individuals can also be plotted as follows (Figure 4). 


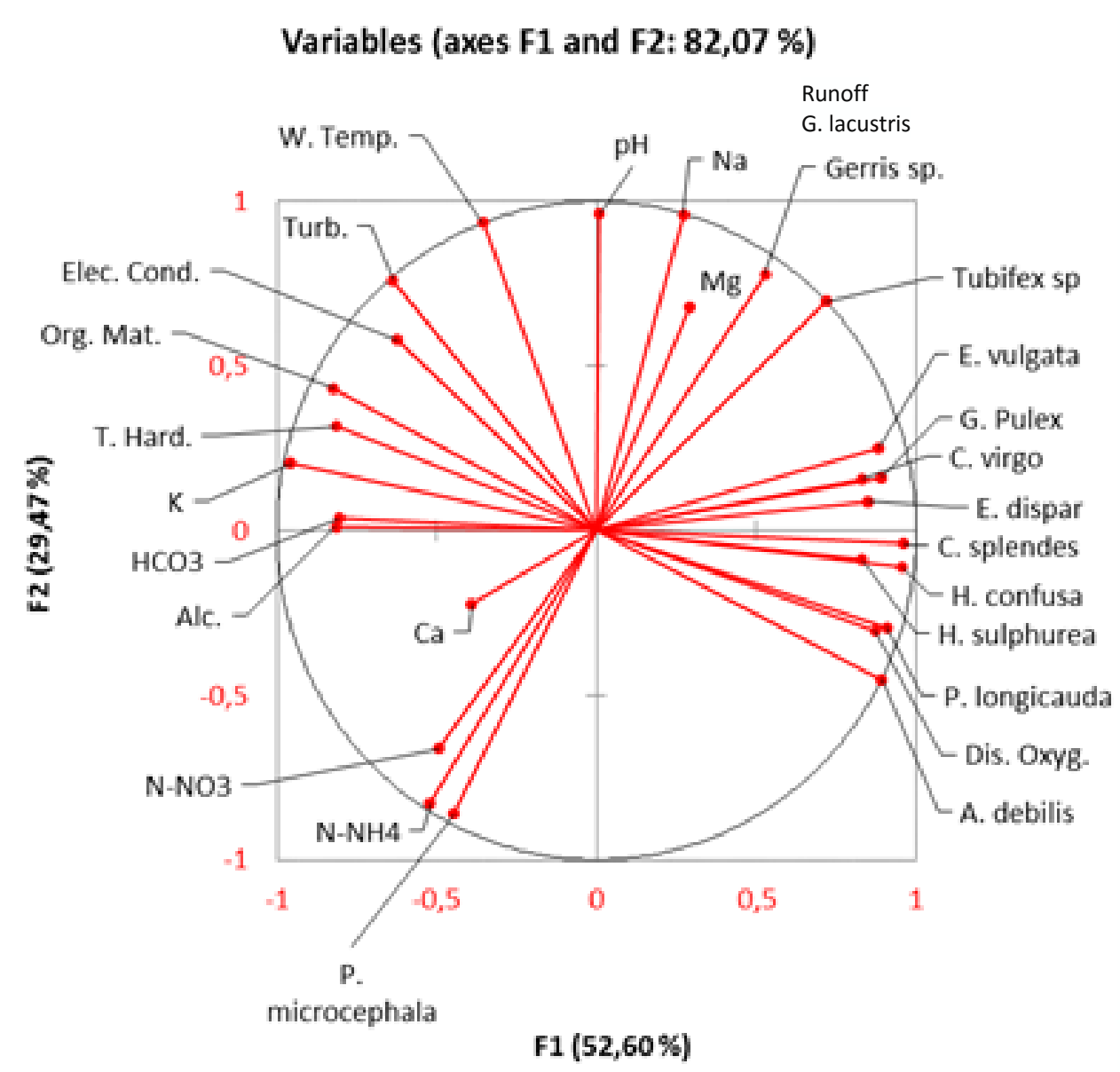

Figure 4. Plot of factor loadings from Principal Component Analysis along principal component axes 1 and 2.

There are two main axes, including F1 and F2 on the canonical diagram plotted above. Variables positioned close to each other on the diagram and to borders of diagram are seen to be related to each other. For example, it has shown that Perlodes microcephala and the parameter ammonium nitrogen $\left(\mathrm{NH}_{4}-\mathrm{N}\right)$ were located close to the borders of diagram from center point and to one another. Therefore, it has found to be a high and significant relationship between these two individuals since their factor loadings are close to - 1 . In a fashion similar to relationship status of these two variables, other related individuals and parameters could also be interpreted. For instance, Palingenia longicauda and dissolved oxygen highly and positively loaded to F1. When examined the analysis results all together, it can be seen that there also exists similar relationships. Therefore, it can be determined by means of this analysis that macroinvertebrate individuals respond much better to which individuals or variable (e.g., water quality parameter) of the habitat in which it dwells than to the others. The following Table 4 demonstrates indicator macroinvertebrates individuals and macroinvertebrates ones associated with these individuals and/or a set of water quality parameters according to the analysis results. 
Table 4. Relationship situations of macroinvertebrate individuals and of water quality parameters of the habitat

\begin{tabular}{|c|c|c|c|}
\hline $\begin{array}{l}\text { Water quality } \\
\text { parameters }\end{array}$ & Macroinvertebrate individuals & $\begin{array}{l}\text { Factor } \\
\text { status }\end{array}$ & $\begin{array}{l}\text { Factor } \\
\text { type }\end{array}$ \\
\hline $\begin{array}{l}\mathrm{Na} \text {, Water } \\
\text { temperature, Runoff, } \\
\mathrm{pH}\end{array}$ & Gerris lacustris (Hemiptera) & + & $\mathrm{F} 2$ \\
\hline $\begin{array}{l}\mathrm{Na} \text {, Water } \\
\text { temperature, Runoff, } \\
\mathrm{pH}\end{array}$ & Perlodes microcephala (Plecoptera) & - & $\mathrm{F} 2$ \\
\hline Ammonium & Gerris lacustris (Hemiptera) & - & $\mathrm{F} 2$ \\
\hline Ammonium & Perlodes microcephala (Plecoptera) & + & $\mathrm{F} 2$ \\
\hline $\begin{array}{l}\text { Potassium, } \\
\text { Alcalinity, Organic } \\
\text { matter, } \mathrm{HCO}_{3} \text {, Total } \\
\text { Hardness }\end{array}$ & $\begin{array}{l}\text { Gammarus pulex (Amphipoda), Ephemera vulgata } \\
\text { (Ephemeroptera), Ecdyonurus dispar (Ephemeroptera), } \\
\text { Palingenia longicauda (Ephemeroptera), Heptagenia } \\
\text { sulphurea (Ephemeroptera), Calopteryx splendens } \\
\text { (Odonata), Calopteryx virgo (Odonata), Anisops debilis } \\
\text { (Hemiptera), Habroleptoides confusa (Ephemeroptera) }\end{array}$ & - & F1 \\
\hline Dissolved oxygen & $\begin{array}{l}\text { Gammarus pulex (Amphipoda), Ephemera vulgata } \\
\text { (Ephemeroptera), Ecdyonurus dispar (Ephemeroptera), } \\
\text { Palingenia longicauda (Ephemeroptera), Heptagenia } \\
\text { sulphurea (Ephemeroptera), Calopteryx splendens } \\
\text { (Odonata), Calopteryx virgo (Odonata), Anisops debilis } \\
\text { (Hemiptera), Habroleptoides confusa (Ephemeroptera) }\end{array}$ & + & $\mathrm{F} 1$ \\
\hline
\end{tabular}

\section{UPGMA results}

Monthly similarity analysis was derived from distance matrix and dendrogram using UPGMA analysis. Distance matrix table (Table 5) was calculated from UPGMA between months and monthly number of macroinvertebrate individuals. In Table 5, it was seen that the values of August were different according to the values of other months.

Table 5. Monthly Macroinvertebrate Distance matrix based on Pearson coefficient

$\begin{array}{lcccccccccccc} & \text { Jan } & \text { Feb } & \text { Mar } & \text { Apr } & \text { May } & \text { June } & \text { July } & \text { Aug } & \text { Sep } & \text { Oct } & \text { Nov } & \text { Dec } \\ \text { Jan } & 0 & 18,8 & 57,6 & 44,4 & 35,8 & 35,8 & 53,2 & 127,2 & 35,8 & 95,5 & 60,4 & 40,51 \\ \text { Feb } & 0 & 88,54 & 57,97 & 21,2 & 21,2 & 35,9 & 118,9 & 21,2 & 68,2 & 34,9 & 31,1 \\ \text { Mar } & & & 0 & 29,7 & 76,6 & 76,6 & 87,3 & 119,3 & 76,6 & 120,1 & 109,6 & 114,6 \\ \text { Apr } & & & & 0 & 64,3 & 64,3 & 74,6 & 116,3 & 64,3 & 74,6 & 58,9 & 70,1 \\ \text { May } & & & & 0 & 0 & 11,2 & 107,7 & 0 & 110,7 & 80,7 & 77,9 \\ \text { June } & & & & & 0 & 11,2 & 107,7 & 0 & 110,7 & 80,69 & 77,88 \\ \text { July } & & & & & & 0 & 60,94 & 11,2 & 114,8 & 88,9 & 89,8 \\ \text { Aug } & & & & & & & 0 & 107,7 & 110,6 & 114,5 & 122,1 \\ \text { Sep } & & & & & & & & 0 & 110,7 & 80,7 & 77,8 \\ \text { Oct } & & & & & & & & & 0 & 26,4 & 38,7 \\ \text { Nov } & & & & & & & & & & 0 & 9,7 \\ \text { Dec } & & & & & & & & & & & 0\end{array}$


Output UPGMA dendrogram (Figure 5) had been used to compare the months using number of macroinvertebrate individuals. According to dendrogram, some months could be seen to generated similarity groups such as January and February or March and April. Therefore, it has found to be a seasonal difference was occurred when considered monthly distributions of macroinvertebrates collected from forested watersheds.

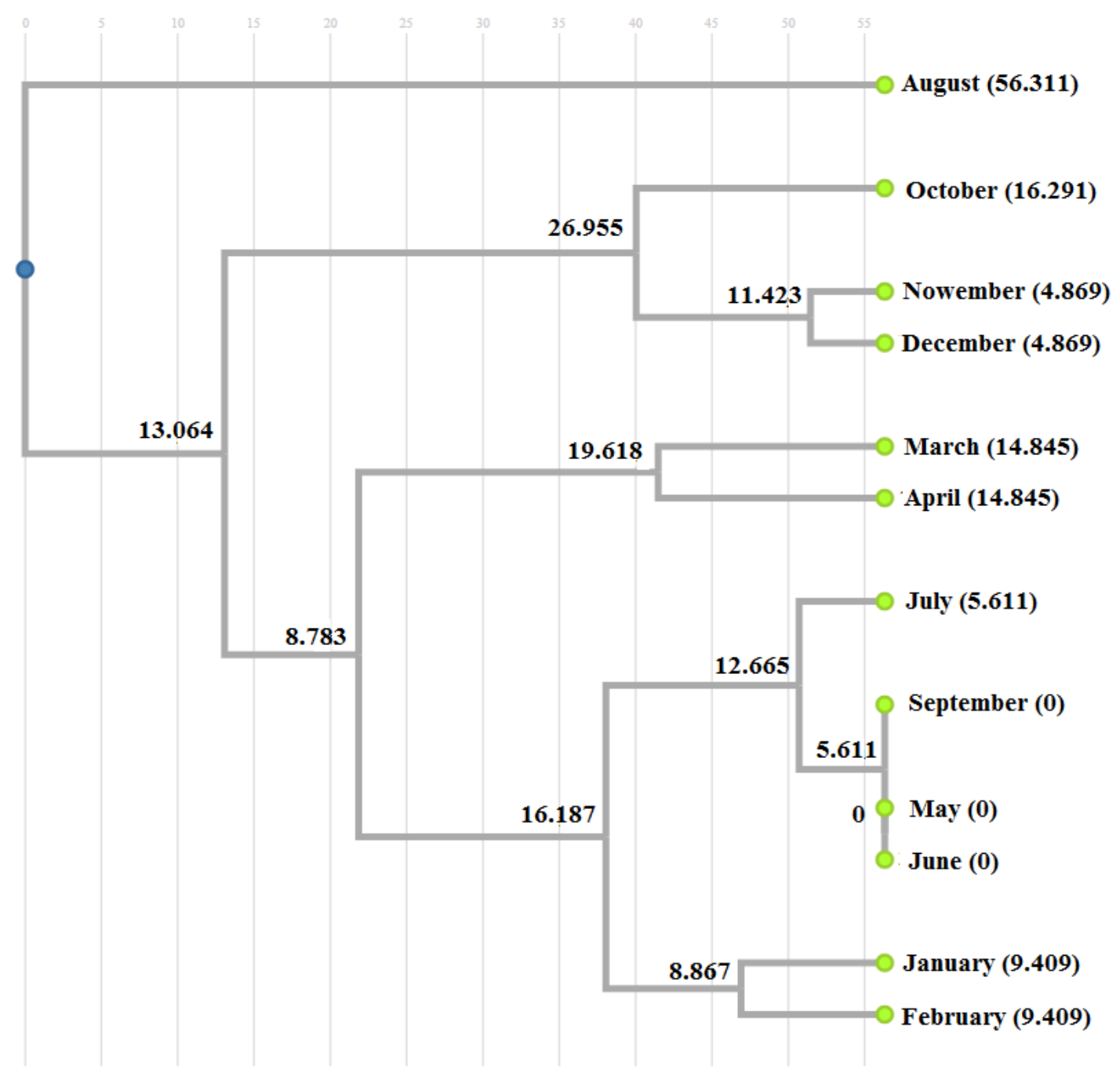

Figure 5. Output UPGMA Dendrogram

Monthly macroinvertebrate distance matrix and dendrogram shows that the numbers of macroinvertebrate individuals are distributed with a seasonal effect.

\section{Discussion}

This study put forward relationships between macroinvertebrates individuals and measured water quality parameters. The populations of Gammarus pulex and EPT (Ephemeroptera, Plecoptera and Trichoptera) macroinvertebrates increased as the amount of dissolved oxygen rised. Maltby (1995) determines that the parameter of dissolved oxygen is a significant source of stress, which is caused hypoxia for 
Gammarus pulex. Stoyanova et al. (2014) suggest that the populations of Ephemeroptera and Plecoptera increased significantly in the periods, especially in spring and autumn, when dissolved oxygen parameter augmented quantitatively. In this research, it was also observed that the number of macroinvertebrates individuals, particularly of Ephemeroptera, increases in the spring as the amount of dissolved oxygen rises.

This study has shown that the population of Gerris lacustris increases with an increase in the parameters including sodium concentration, water temperature, runoff and $\mathrm{pH}$ but its population reduces with ammonium concentration. The ammonium concentration generally increases depending on anthropogenic effects and this increase leads to an alienation of the habitat environments from their natural state (Zhang et al., 2015). In line with the findings of this study, Andersen (1982) indicates that Gerris lacustris is a reliable indicator of habitat conditions affected in no or too little way by anthropogenic effects.

Plecoptera and Ephemeroptera display different behaviours in terms of seasonal water temperature. Plecoptera mostly prefer colder water temperatures while Ephemeroptera occur more frequently at warmer temperatures (Haidekker and Hering, 2008). This might arise from enzyme activities of these macroinvertebrates that are adapted to different temperatures (Pritchard et al. 1996). We found a negative relationship between Perlodes microcephala belonging to Plecoptera and water temperature. Therefore, Perlodes microcephala being an individual of Plecoptera differs from other macroinvertebrates individuals in terms of both the interaction and its responses to the water quality characteristics. When Figure 3 and Figure 4 are appraised together, it becomes evident that populations of other macroinvertebrates individuals, excluding Perlodes microcephala, have increased especially in spring months. In general, it is seen that Perlodes microcephala's continuity maintains in the habitat by adapting itself to this decrease while falling water temperature, whereas other individuals not adapted to temperature drop move away from the environment.

The study reveals that dominant macroinvertebrates individual was Gammarus pulex while dominant macroinvertebrates order was Ephemeroptera. Macroinvertebrate individuals of the order Ephemeroptera and Gammarus pulex constitute the indicator ones for clean streams. When taking a look at the trophic properties, Gammarus pulex is clearly seen to be a detritivorous individual, which is fed with dead organic matters (Maltby et al., 2012). Ephemeroptera also acts as an herbivorous individual, in addition to feeding dead organic matters (Patten, 2013). Besides, macroinvertebrate individuals of the order Ephemeroptera also need a high concentration of oxygen, as in individual of Gammarus pulex (Wetzel, 2001). Therefore, these individuals providing a large amount of litter to the soil abound in streams of forested watersheds with plentiful oxygen content, and the findings of our research also supports this notion.

The two seasonal effects regarded as flow and water temperature in this study are found to have a positive high relationship with Gerris lacustris but a negative one with Perlodes microcephala. Aside from water temperature and flow, individual of Gerris lacustris are also found to be closely related to the parameters sodium (Na) and $\mathrm{pH}$. Unlike our findings, Girgin et al. (2003) have established that individual of Gerris lacustris are in a close relationship with organic matter and ammonia. When viewed from Table 3 and Figure 3, additionally, sodium and $\mathrm{pH}$ values have also shown to rise as the parameters water temperature and flow increase. 
Another inference that can be made from the results of our present study is that macroinvertebrates, which reflect the stream health and integration level in a watershed with a land use consisting chiefly of the forested land (close to the natural area), become evident to be individuals adapted to the streams with which these forested lands interact mostly. Because, it will enable the researches to be conducted in the future under other land uses to compare through this study which expresses to denaturalize and determines the level of integration.

In this study, it was observed that the flow and climate dynamics of watershed was changed by seasonal effect. Results of distance matrix and dendrogram were also support this conclusion on numbers of macroinvertebrate individuals. According to Output UPGMA dendrogram, the different number of macroinvertebrate individuals can be seen as the reflect of variable seasonal effect. Especially in August, the runoff was being reduced considerably or water temperature was extremely increased. The main conclusion of this study show that these streamwater characteristics may directly or indirectly affects the macroinvertebrate assemblages.

\section{REFERENCES}

[1] Abdi, H., Williams, L. J. (2010): Principal Component Analysis. - Wiley Interdisciplinary Reviews: Computational Statistics 2(4): 433-459.

[2] Allan, J. D., Castillo, M. M. (2007): Stream ecology: structure and function of running waters. - Springer Science \& Business Media.

[3] Andersen N. M. (1982): The semiaquatic bugs (Hemiptera, Gerromorpha) phylogeny, adaptations, biogeography and classification. - Scandinavian Science Press Ltd..

[4] Beylich, A.A., Laute, K. (2012): Seasonal and annual variations of surface water chemistry, solute fluxes and chemical denudation in a steep and glacier-fed mountain catchment in western Norway (Erdalen, Nordfjord). - Catena 96: 12-27.

[5] Chang, M. (2012): Forest Hydrology: An Introduction to Water and Forests. - CRC press.

[6] Connell-Buck, C.R., Medellín-Azuara, J., Lund, J.R., Madani, K. (2011): Adapting California's water system to warm vs. dry climates. - Climatic Change 109(1): 133-149.

[7] García-Roger, E. M., del Mar Sánchez-Montoya, M., Gómez, R., Suárez, M. L., VidalAbarca, M. R., Latron, J., Prat, N. (2011): Do seasonal changes in habitat features influence aquatic macroinvertebrate assemblages in perennial versus temporary Mediterranean streams? - Aquatic sciences 73(4): 567-579.

[8] Gies, M., Sondermann, M., Hering, D., Feld, C. K. (2015): A comparison of modelled and actual distributions of eleven benthic macroinvertebrate species in a Central European mountain catchment - Hydrobiologia 758(1): 123-140.

[9] Girgin, S., Kazanc1, N., Dügel, M. (2003): Ordination and classification of macroinvertebrates and environmental data of a stream in Turkey. - Water Science and Technology 47(9): 133-139.

[10] Haidekker, A., Hering, D. (2008): Relationship between benthic insects (Ephemeroptera, Plecoptera, Coleoptera, Trichoptera) and temperature in small and medium-sized streams in Germany: A multivariate study. - Aquatic Ecology 42:463-481.

[11] Johnson, P.D., Brown, K.M., Covell Jr, C.V. (1994): A comparison of the macroinvertebrate assemblage in Doe Run Creek, Kentucky: 1960 and 1990. - Journal of the North American Benthological Society, 496-510.

[12] Jolliffe, I. (2005): Principal Component Analysis. - John Wiley \& Sons, Ltd.

[13] Jolliffe, I. (2011): Principal Component Analysis. - In: International Encyclopedia of Statistical Science (pp. 1094-1096). Springer Berlin Heidelberg. 
[14] Leps, M., Tonkin, J. D., Dahm, V., Haase, P., Sundermann, A. (2015): Disentangling environmental drivers of benthic invertebrate assemblages: The role of spatial scale and riverscape heterogeneity in a multiple stressor environment. - Science of the Total Environment 536: 546-556.

[15] Maltby, L. (1995): Sensitivity of the crustaceans Gammarus Pulex (L.) and Asellus Aquaticus (L.) to short-term exposure to hypoxia and unionized ammonia: observations and possible mechanisms. - Water Research 29(3): 781-787.

[16] Maltby, L., Clayton, S.A., Wood, R.M., McLoughlin, N. (2002): Evaluation of the Gammarus pulex in situ feeding assay as a biomonitor of water quality: Robustness, responsiveness, and relevance. - Environmental Toxicology and Chemistry 21: 361-368.

[17] Masese, F.O., Kitaka, N., Kipkemboi, J., Gettel, G.M., Irvine, K., McClain, M.E. (2014): Litter processing and shredder distribution as indicators of riparian and catchment influences on ecological health of tropical streams. - Ecological Indicators 46: 23-37.

[18] McCord, S.B., Kuhl, B.A. (2013): Macroinvertebrate community structure and its seasonal variation in the Upper Mississippi River, USA: a case study. -.Journal of Freshwater Ecology 28(1): 63-78.

[19] Nei, N., W. Li. (1979): Mathematical model for studying genetic variations in terms of restriction endonucleases. - Proc. Natl. Acad. Sci. USA 76: 5269-5273.

[20] Patten, B.C. (2013): Systems Analysis and Simulation in Ecology. Elsevier, Amsterdam.

[21] Pritchard, G., Harder, L.D., Mutch, R.A. (1996): Development of aquatic insect eggs in relation to temperature and strategies for dealing with different thermal environments. Biological Journal of the Linnean Society 58:221-244.

[22] Rao, C. R. (1964): The use and interpretation of principal component analysis in applied research. - Sankhyā: The Indian Journal of Statistics Series A: 329-358.

[23] Roy, A.H., Faust, C.L., Freeman, M.C., Meyer, J.L. (2005): Reach-scale effects of riparian forest cover on urban stream ecosystems. - Canadian Journal of Fisheries and Aquatic Sciences 62(10): 2312-2329.

[24] Serengil, Y., Gökbulak, F., Özhan, S., Hizal, A., Şengönül, K. (2007): Alteration of stream nutrient discharge with increased sedimentation due to thinning of a deciduous forest in Istanbul. - Forest ecology and management 246(2): 264-272.

[25] Stoyanova, T., Vidinova, Y., Yaneva, I., Tyufekchieva, V., Parvanov, D., Traykov, I., Bogoev, V., (2014): Ephemeroptera, Plecoptera and Trichoptera as Indicators for Ecological Quality of the Luda Reka River, Southwest Bulgaria. - Acta Zoologica Bulgarica 66(2): 255-260.

[26] Sundermann, A., Leps, M., Leisner, S., Haase, P. (2015): Taxon-specific physicochemical change points for stream benthic invertebrates. - Ecological Indicators 57:314323.

[27] Wetzel, R.G., (2001): Limnology: Lake and River Ecosystems. Academic Press, 1006 pp.

[28] Vaughan, I.P., Ormerod, S.J. (2012): Large- scale, long- term trends in British river macroinvertebrates. - Global Change Biology 18(7): 2184-2194.

[29] Zhang, W. S., Swaney, D. P., Li, X. Y., Hong, B., Howarth, R. W., Ding, S. H. (2015): Anthropogenic point-source and non-point-source nitrogen inputs into Huai River basin and their impacts on riverine ammonia-nitrogen flux. - Biogeosciences 12(14): 42754289. 